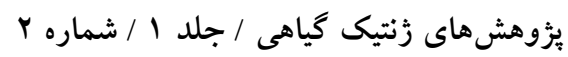

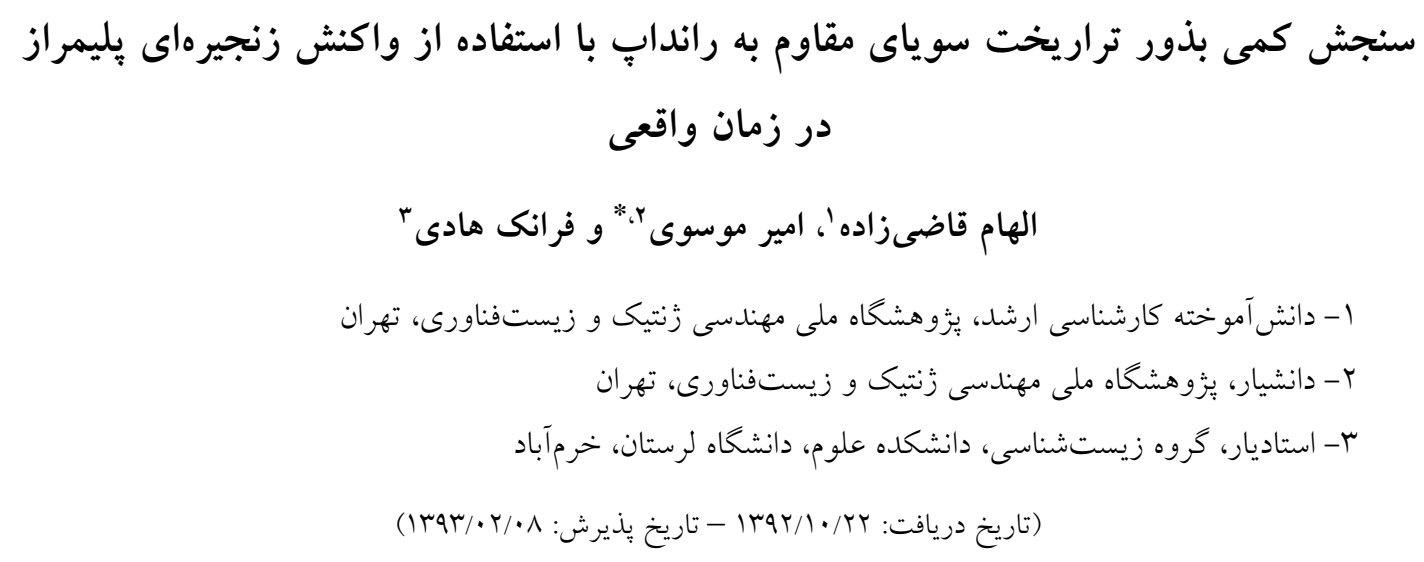

جكيده

امروزه زيست فناورى گياهى راهكار مناسبى را در جهت توسعه مواد غذايى مشتق از محصولات تراريخته فراهم نموده است.

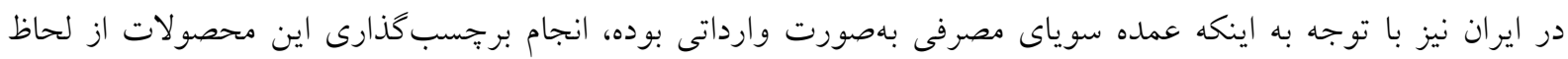

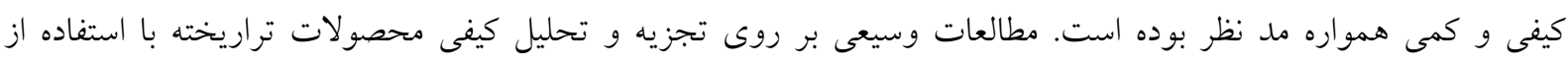

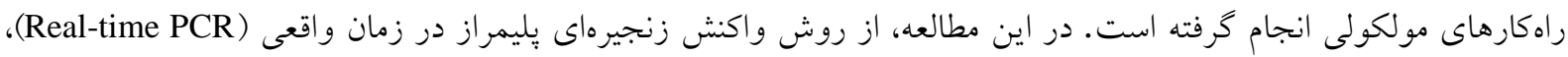

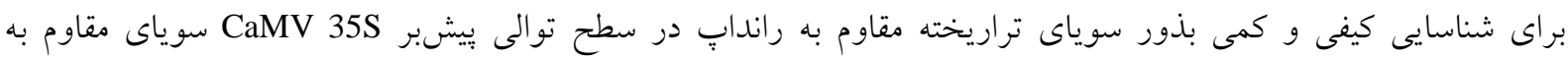
راندابٍ نسبت به توالى زن خانهدار لكتين استفاده شد. بررسىها براى تعيين ميزان دقيق حضور مواد تراريخته در دو نمونه بذر لـر

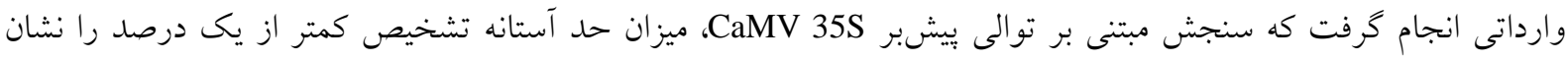

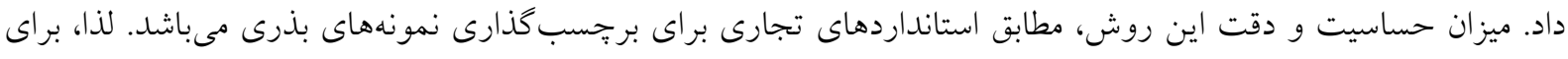

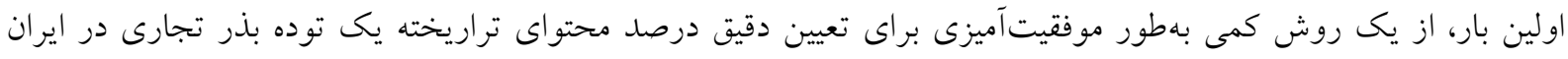
استفاده بهعمل آمد.

وازگَان كليدى: حد آستانه، سوياى مقاوم به رانداب، كَاهان تغييريافته زنتيكى 
كميسيون استاندارد ارويا، تمامى زير واحدهاى ارويايى را

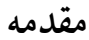
وادار به برجسبدار كردن محصولات حاوى مقادير بالاتر

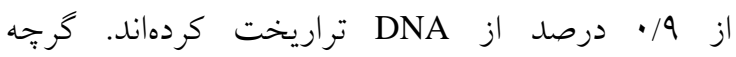
برجسبدار كردن محصولات ترازن، توسط بسيارى از

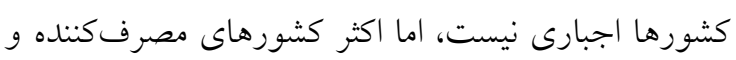

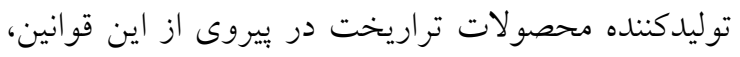

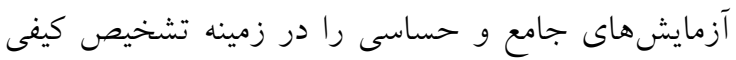
(Gurel et al., و كمى درصد عناصر ترازن انجام مى

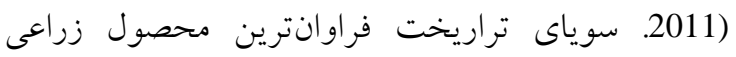

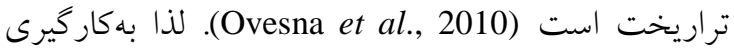
روشهاى مناسب براى شناسايى دقيق سوياى تراريخت ضرورى مىباشد. يكى از روشهاى حساس و دقيق براى

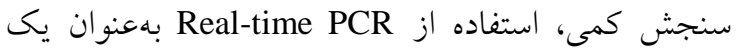
روش كمى (QPCR) مىباشد (Marmiroli et al., 2008). در روش Real-time PCR، سنجش كمى در مرحله نمايى صورت مى گيرد، يعنى به جاى تعيين محصول تكثير يافته

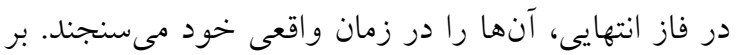
اساس شدت سيكنال فلورسنت توليد شده در طول واكنش، ميزان تكثير اندازهكيرى شده و نمودار استاندارد بهنعوان مرجع براى كمى كردن اطلاعات حاصل به بهار مىرود (Ingham et al., 2001; Paoletti et al., 2006) محتواى GMO يك نمونه، عبارت است از درصد مقدار ماده تغييريافته زنتيكى در مقدار كل عناصر. براى تخمين

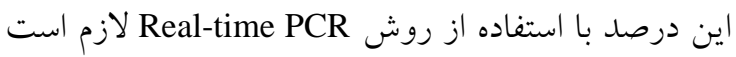

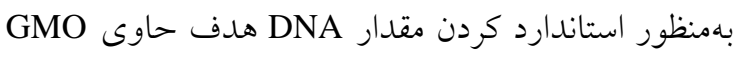
خاص در هر واكنش از يك زن خانهدار بهعنوان كتترل

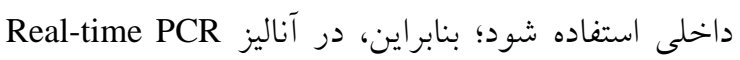
يك PCR براى شناسايى توالى DNA تغييريافته مورد نظر

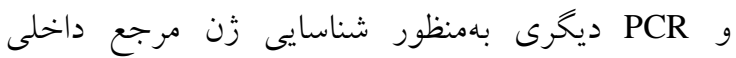
طراحى شده است. براى كمى يابى صحيح ماده تراريخت،

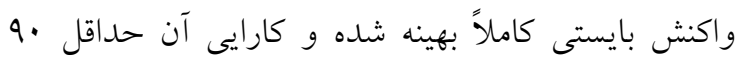
درصد باشد. كارايى PCR تحت تأثير عوامل بسيارى مانند طراحى آغازگر، تركيب مخلوط واكنش و حضور فزاينده و كاهندهها دارد (Hodst-Jensen et al., 2006 
روش ارائه شده توسط Murray و Murry ) Thompson كه مورد تأييد سازمان استاندارد (and Thompson, 1980 جهانى مىباشد، انجام شد. با اين تفاوت كه در بافر CTAB

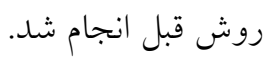
طراحى آغازگر و كاوشخر براى واكنش زنجيرهاى

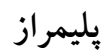
آغازكرهاى طراحى شده در اين واكنش براى عناصر رنى

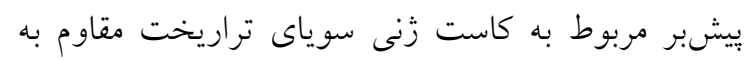

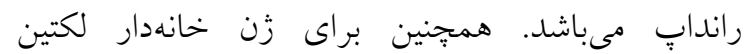

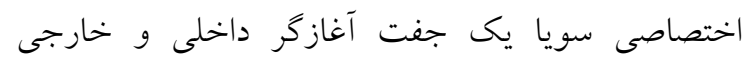
طراحى و ساخته شد. بهنظور طراحى آغازكرها از برنامه (Untergasser et al., 2007) primer3 كاوشگرها از شركت Liege بلزيك خريدارى شدند. مشخصات آغازكرها و كاوشكرهاى استفاده شده در اين مطالعه در جدول آمآمده است.

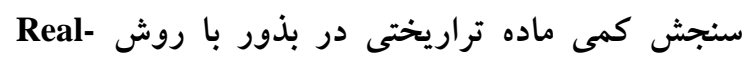
:time PCR

واكنش PCR بر روى نمونههاى CRM شامل ل، 0 و //.

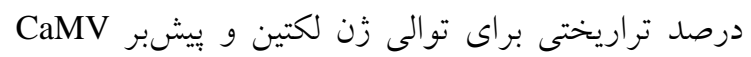

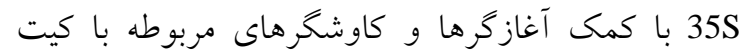

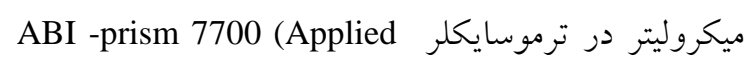
Biosystems, Foster City, CA, USA) منظور در IV/0 ميكروليت Taqman Universal PCR Taqman Universal PCR ميكروليتر IV/0 Master Mix Master Mix

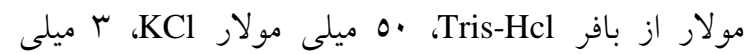

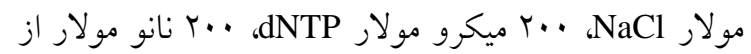

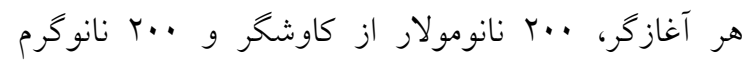

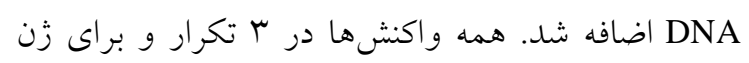
لكتين و توالى بيشبر بهصورت جداكانه انجام كرفت.

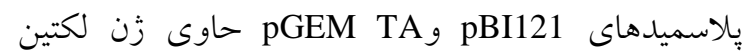

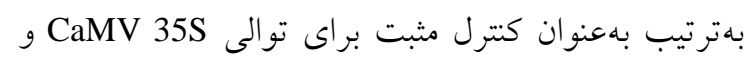

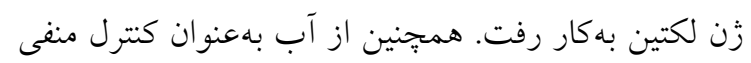
و يا واكنش بدون DNA الكو (NAC) تأييد عدم آلودخى استفاده شد. (al., 2009; Bergerova et al., 2011 عمده سوياى مصرفى ايران بهصورت بذور و نمونههاى

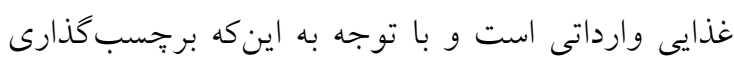
در تودهاى وارداتى فقط در سطح كيفى انجام مى گرددد،

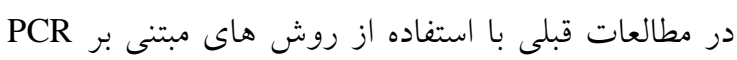

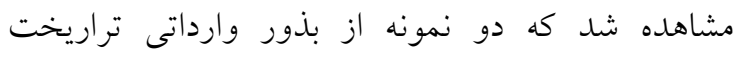

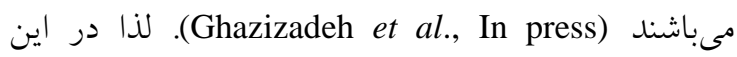

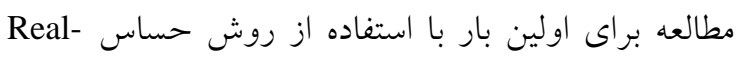
time PCR بذور سويا وارداتى مذكور از نظر كمى سنجيده شده

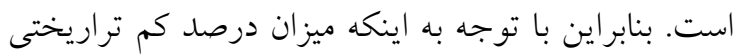
در برخى از بذور وارداتى وجود دارد، مىتوان از اين بن باني يروتكل دقيق، براى سنجش كمى و در صورت لزوم بر جسب گذارى آنها استفاده نمود. مواد و روشها مواد گياهى: بذور گياه سوياى تراريخت از يك نمونه

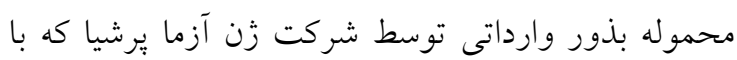

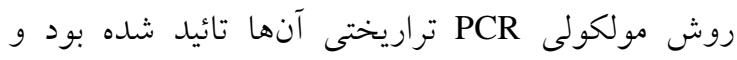

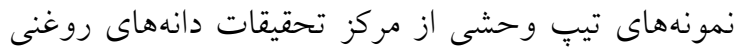
تهيه كرديد. مواد مرجع قابل اعتماد ( Certified Reference (Material بهصورت يودرهاى Fluka (Buchs SG, Switzerland) هموزنيزه شدهى خشى شامل 1، 0 و //• درصد سوياى تراريخت خريدارى گرديد.

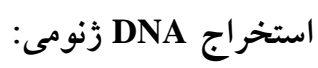

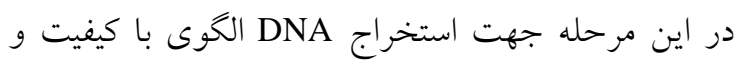

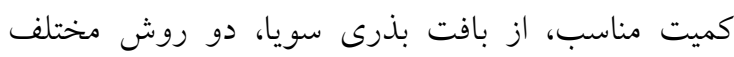
مورد ارزيابى و مقايسه قرار كرفت.

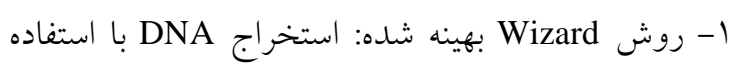
از روش Wizard (Spoth and Strauss, 1999) كه تأييد شده از طرف سازمان استاندارد جهانى مىباشد، صورت

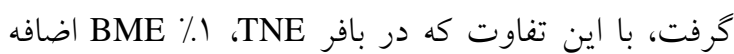
شد و بقيه مراحل كار همانند يروتكل اجرايى اجرا شد.

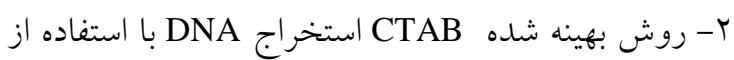


جدول ا- مشخصات آغاز كَرها و كاوشخرهاى استفاده شده در اين مطالعه

Table 1. Characteristics of the primers and probe used in this study

\begin{tabular}{|c|c|c|c|c|}
\hline & اندازه محصول & & & \\
\hline منبع & تكثير يافته & توالى '5 به '3 & ن ام & اختصاصيت \\
\hline Reference & $\begin{array}{l}\text { Amplicon } \\
\text { length (bp) }\end{array}$ & Sequence $\left(5^{\prime}-3^{\prime}\right)$ & Name & Specificity \\
\hline (Lipp et al., 1999) & 195 & $\begin{array}{l}\text { GCTCCTACAAATGCCATCAGATA } \\
\text { GTGGGATTGTGCGTCA }\end{array}$ & $35 \mathrm{~S} 1-35 \mathrm{~S} 2$ & ييشبر 35S \\
\hline (Corbisier et al., 2005) & & $\begin{array}{l}\text { FAMCAAAGATGGACCCCCACCCA } \\
\text { CGTAM }\end{array}$ & $\begin{array}{l}\text { 35S-FAM } \\
\text { (probe) }\end{array}$ & $35 \mathrm{~S}$ promoter \\
\hline (Lin et al., 2000) & 118 & $\begin{array}{l}\text { GCCCTCTACTCCACCCCCATCCGC } \\
\text { CCATCTGCAAGCCTTTTTGTG }\end{array}$ & GMO3-GMO4 & لكتين \\
\hline (Corbisier et al., 2005) & & $\begin{array}{l}\text { TAMAACCGGTAGCGTTGCCAGCT } \\
\text { TCG-VIC }\end{array}$ & $\begin{array}{l}\text { Lectine-TMP } \\
\text { (probe) }\end{array}$ & Lectine \\
\hline
\end{tabular}

با توسعه وسيع گياهان تراريخت و بهكارگيرى اين محصولات در فرآوردههاى غذايى، برجسبك خذارى توده

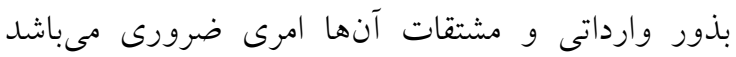

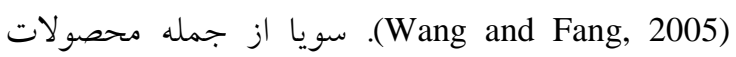

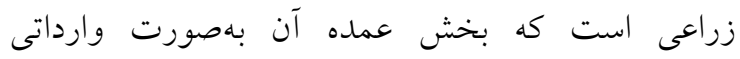
مىباشد. لذا، بهكارگيرى روش و يروتكل مناسب جهت ارزيابى دقيق ميزان تراريختى اين محصول از اهميت بالايى برخوردار است. استخر اجDNA با كيفيت اولين قدم در آناليز محصولات زراعى تراريخت مىباشد Vrablik) بنابراين استخراج DNA al., 2012) انجام كرديد و با توجه به مقايسه غلظت و كيفيت DNA حاصل، روش CTAB براى تهيه DNA مناسب تشخيص

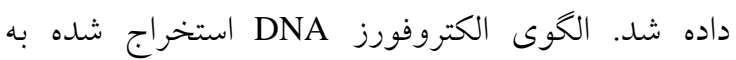
روش هاى Wizard و از بافت بذور سويا در شكل آ آمده است. در مطالعه حاضر، با روش كمى بسيار دقيق تكثير محصولات در فاز نمايى سنجيده شد، لذا دقت بيشترى نسبت به ساير روشهاى PCR كه ميزان محصولات را در پِايان واكنش مىسنجند، دارد. بهكارگيرى روش Real-time PCR براى تعيين ميزان تراريختى محصولاتى كه حاوى ميزان كمى درصد تراريختى مىباشند و يا مشتقات غذايى بردازش يافته مناسب مىباشد؛ زيرا ممكن است واكنش زنجيرهاى بليمراز قادر به تشخيص ميزان كم عنصر دستورزى شده
شرايط واكنش شامل يك جرخه در دماى ل0 درجه

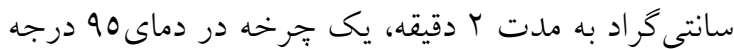

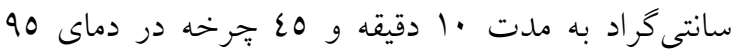

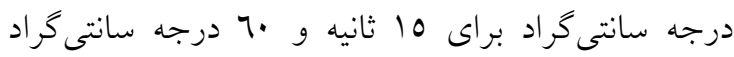
براى ا دقيقه انجام شد. شدت فلورسنت بهطور بيوسته در برائ حين واكنش PCR نمايش داده شده است. براى نمودارهاى تكثير زن لكتين و يِيشبر 35S ارزش حد

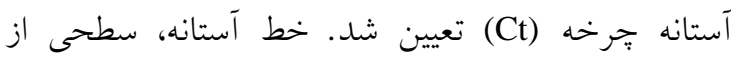
شناسايى مىباشد كه شدت فلورسنت بالاتر از خط زمينه است. اين سطح در فاز لكاريتمى قرار داشته در نتيجه، سيكل آستانه (Ct) يك معيار تشخيص بوده كه نشان

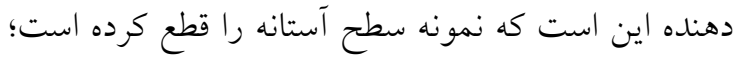

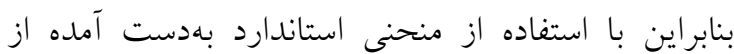

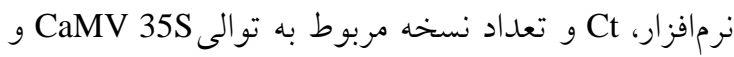
زن خانهدار لكتين در نمونهها تخمين زده شد. در نهايت درصد تراريختى برحسب 100 × مقدار لكتين / مقدار تراريختى CaMV 35S = CaMV 35S تراريختى محاسبه شد. با ايجاد سرى رقتهاى DNA هدف حضور

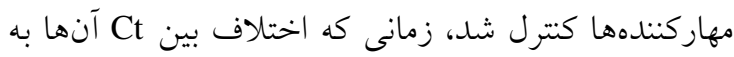
r/r رسيد مىتوان كفت هيج گونه مهاركنندهاى وجود ندارد و از نمونه DNA بهعنوان الكو براى واكنش PCR مى توان استفاده نمود. 
توالىهاى مذكور در سرى رقتهاى نمونههاى CRM بوده است و نقطه قرمز بهدست آمده بر روى منحنى استاندارد مربوط به نمونه كنترل مثبت مىباشد. شيب خط ANOVA مربوط به هر منحنى استاندارد با كمك نرمافزار بهدست آمده است. معادلههاى مربوط به منحنىهاى

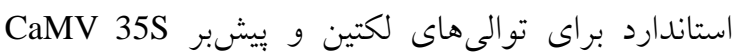
y = بهترتيب بهصورت 12.369 و 0.5392x + 16.65 مىباشد. همجنين حد آستانه و تعداد نسخه براى هر توالى محاسبه و در جدول r آمده است، سبس درصد تراريخت بودن را بر اساس درصد نسبت ميزان CaMV 35S بر مقدار لكتين محاسبه شد (جدول

در اين مطالعه آناليز بر روى دو نمونه از بذور وارداتى

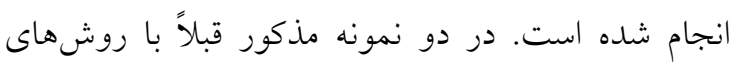
مولكولى PCR معمولى، حضور عناصر تراريخت بهصورت كيفى و نيمه كمى كزارش شلده است (Ghazizadeh et al., Inpress) است با روش حساس Real-time PCR ميزان دقيق عناصر تراريخت در دو نمونه بررسى شود. نتايج نشان داد نمونه اول داراى 9VA/ • درصد و نمونه دوم داراى OV/ • درصد عنصر تراريختى مىباشد.

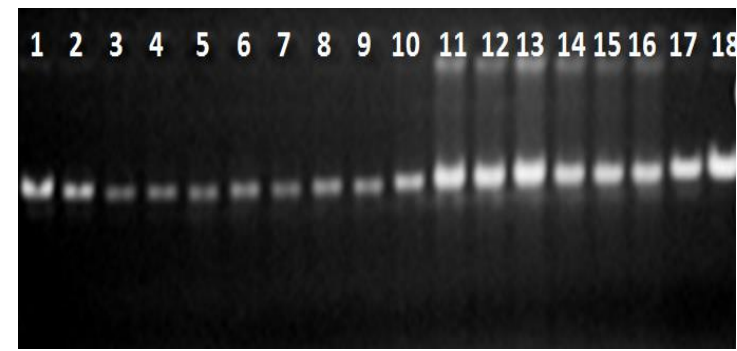

B
در فاز نهايى نباشد. از طرف ديخر بعضى از مشتقات غذايى حاوى جندين عنصر تراريختى هستند، در اين حالت بايستى درصد تراريختى هر عنصر بهطور دقيق

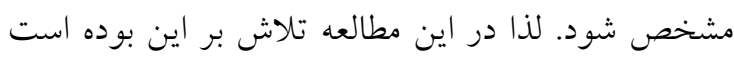
تا براى اولين بار در كشور با روش دقيق Real-time PCR ميزان تراريختى بذور وارداتى تعيين و يك يروتكل جامع با حداقل خطا براى تشخيص سريع GMOs در تمامى

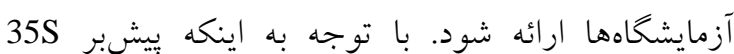
ويروس موزاييك كلم در حدود 90 درصد محصولات تراريخت تجارى وجود دارد، لذا يكى از مهمترين كزينهها براى غربالخرى محصولات تراريخت زراعى مىباشد (Lin et al., 2000). بنابراين ميزان فلورسنت توالى لكتين و CaMV 35S در سرى رقتهاى مختلف نمونهاى استاندارد CRM و دو نمونه مجهول مربوط به بذور وارداتى محاسبه شد. منحنى استاندارد براى عنصر اختصاصى CaMV 35S و زن لكتين بهعنوان يك كنترل داخلى رسم گرديد. منحنى هاى استاندارد مربوط به به ليه توالىهاى لكتين و بيشبر 35S با هم متفاوت بوده و در شكل r نشان داده شدهاند. يك ارتباط خطى بين لكاريتم DNA صحت نتايج، هر واكنشץ بار انجام شد. لكههاى آبى ولى موجود در منحنى استاندارد، حد آستانه بهدست آمده براى

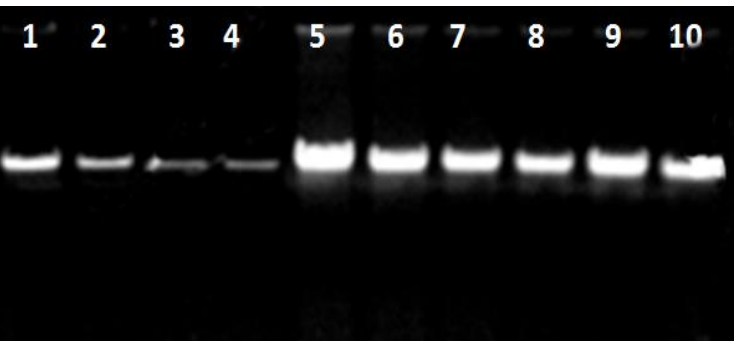

A

شكل ا- مقايسه الكوى الكتروفورزى DNA زنوميك استخراج شده با روشهاى CTAB و Wizard بر روى زل آكارز يك

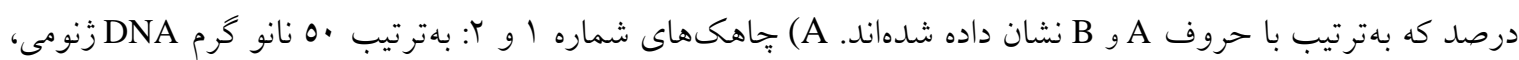

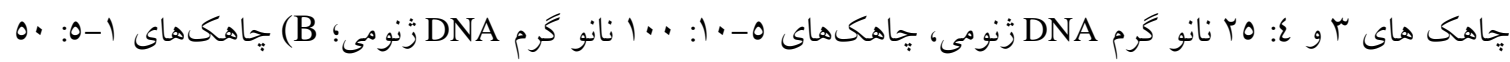

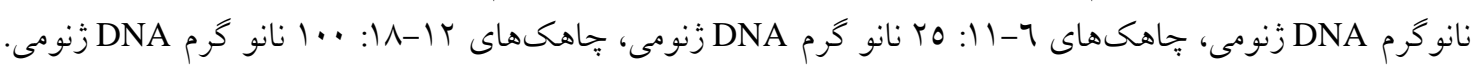

Figure 1. Comparison between electrophoretic patterns of extracted genomic DNA on \%1 agarose using methods of CTAB and Wizard shown by A and B letters, respectively. A) Lanes 1 and 2: $50 \mathrm{ng}$ of DNA, lanes 3 and 4: 25 ng of DNA, lanes 5-10: $100 \mathrm{ng}$ of DNA; B), Lanes 1-5: $50 \mathrm{ng}$ of DNA, lanes 6-11: $25 \mathrm{ng}$ of DNA, lanes 12-18: $100 \mathrm{ng}$ of DNA. 


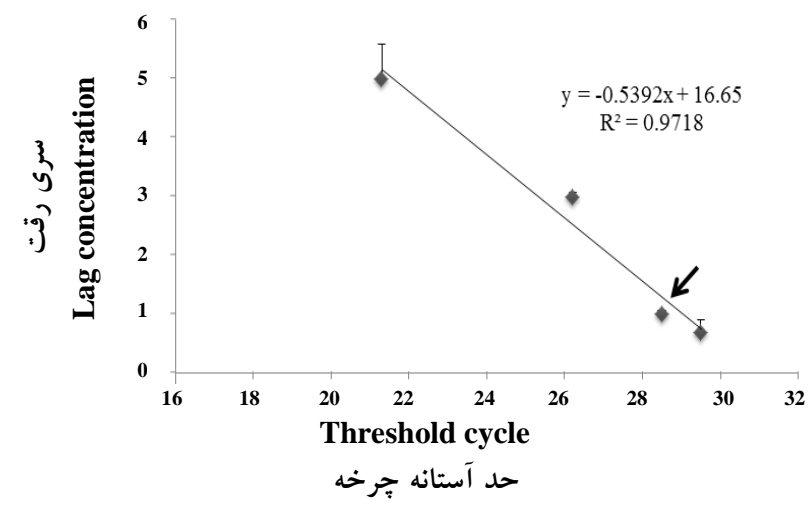

$\mathrm{B}$

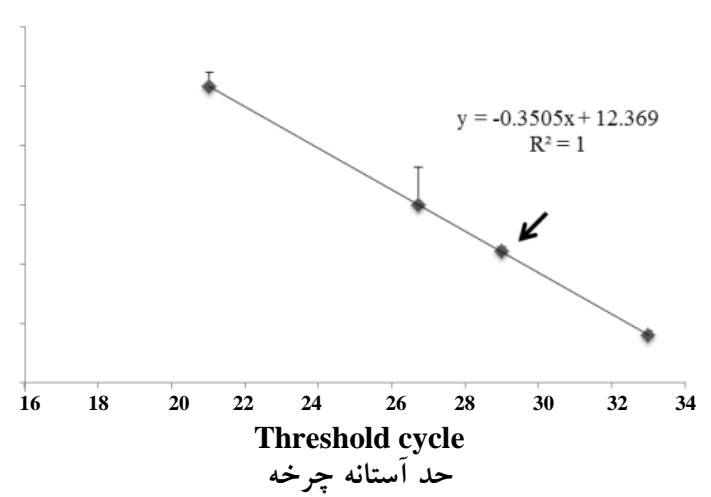

A

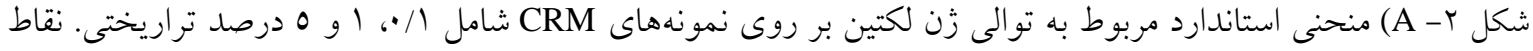

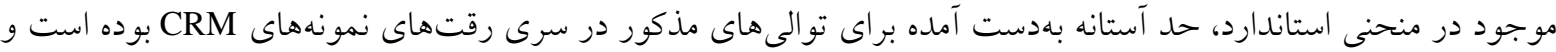

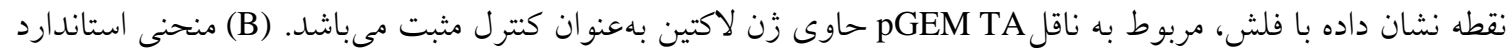

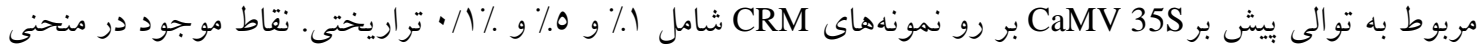

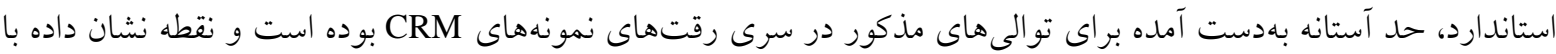

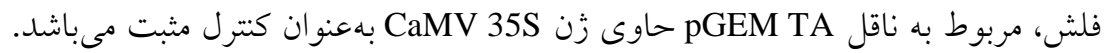

Figure 2. (A), Standard curve of lectin gene for CRM samples containing $0.1 \%, 1 \%, 5 \%$ or $2 \%$ GM-soya. The dot that are indicated by the arrow shows the limit of detection for mentioned sequences in serial dilution of CRM samples. Arrow indicates pGEM TA vector containing lectin gene as the positive control. (B), Standard curve of CaMV $35 \mathrm{~S}$ promoter for CRM samples containing $0.1 \%, 1 \%, 5 \%$ or $2 \%$ GM-soya. The dot that are indicated by the arrow shows the limit of detection for mentioned sequences in serial dilution of CRM samples. arrow indicates pGEM TA vector containing CaMV 35S promoter as the negative control

$$
\text { جدول r- حد آستانه و تعداد نسخه مربوط به توالى لكتين و توالى CaMV 35S براى سرى رقتهاى نمونهاى CRM سذور }
$$

\begin{tabular}{|c|c|c|c|}
\hline \multicolumn{2}{|c|}{ لكتين (Lectine) } & \multicolumn{2}{|c|}{ CaMV 35S } \\
\hline نسخه (Copy) & (حد آستانه جرخهة) Ct & نسخه (Copy) & Ct (حد آستانه جرخهة) \\
\hline 100000 & 21.55 & 100000 & 31.21 \\
\hline 1000 & 27.55 & 1000 & 26.21 \\
\hline 10 & 32.98 & 10 & 28.51 \\
\hline
\end{tabular}

Table 2. Limit of detection and copy No. of Lectin and CaMV 35S sequences in a serial dilution of CRM samples

\begin{tabular}{|c|c|c|c|c|c|}
\hline نمونههاى CRM & CRM sample & $\begin{array}{l}\text { لكتين } \\
\text { Lectin }\end{array}$ & CaMV 35S & $\begin{array}{c}\text { CaMV 35S/ كتين } \\
\text { CaMV 35S/ Lectin }\end{array}$ & درصد عنصر \\
\hline سويا •• تراريخت & 0\% GM-soya & 4.282 & تعيين نشد & تعيين نشد & $\begin{array}{c}\text { تعيين نشد } \\
\text { Not detected }\end{array}$ \\
\hline سويا / / درصد تراريخت & $0.1 \%$ GM-soya & 4.478 & 0.0044 & 0.0010 & 0.10 \\
\hline سويا ا درصد تراريخت & 1\% GM-soya & 4.567 & 0.0461 & 0.0101 & 1.10 \\
\hline سويا ه درصد تراريخت & 5\% GM-soya & 4.502 & 0.2494 & 0.0554 & 5.54 \\
\hline نمونه مجهول شماره | & $\begin{array}{l}\text { Un known } \\
\text { sample No. } 1\end{array}$ & 4.312 & 0.04182 & 0.0097 & 0.97 \\
\hline نمونه مجهول شماره r & $\begin{array}{l}\text { Un known } \\
\text { sample No. } 2\end{array}$ & 4.282 & 0.0244 & 0.0057 & 0.57 \\
\hline
\end{tabular}

جدول r real-time PCR نتايج حاصل از سنجش ميزان درصد عنصر تراريختى بذور سويا با روش

Table 3. Estimation of the percentage of GM material in the soybean seeds by real-time PCR 


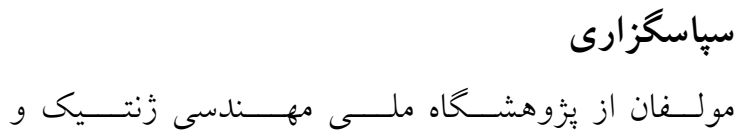

\section{References}

Bergerova, E., Godalova, Z. and Siekel, P. (2011). Combined effect of temperature, pressure and low $\mathrm{pH}$ on the DNA amplification of plant derived foods. Czech Journal of Food Sciences, 29: 337-345.

Corbisier, P., Trapmann, S., Gancberg, D., Hannes, L., Van Iwaarden, P., Berben, G., Schimmel, H. and Emons, H. (2005). Quantitative determination of Roundup Ready soybean (Glycine max) extracted from highly processed flour. Analytical and Bioanalytical Chemistry, 383: 282-290.

Ghazizadeh, E., Mousavi, A., Hadi, F. and Hashemi Sohi, H. Detection of Transgenic Roundup Ready Soybean Seeds by Molecular Methods. Iranian Journal of Biology, In press.

Gurel, F., Arican, E., Gozukirmizi, N. and Ari, S., (2011). Recent molecular tools for detecting transgenic events in genetically modified (GM) crop products. Scientific Research and Essays, 6 : 5091-5099.

Hodek, J., Ovesna, J. and Kucera, L. (2009). Interferences of PCR effectivity: importance for quantitative analyses. Czech Journal of Food Sciences, 27: 42-49.

Holst-Jensen, A., De Loose, M. and Van Den Eede, G. (2006). Coherence between legal requirements and approaches for detection of Genetically Modified Organisms (GMOs) and their derived products. Journal of Agricultural and Food Chemistry, 54: 2799-2809.

Ingham, D.J., Beer, S., Money, S. and Hansen, G. (2001). Quantitative Real-time PCR assay for determining transgene copy number in transformed plants. Biotechniques, 31: 132-4, 136-40.

James, C. (2013). Global Status of Commercialized Biotech/GM Crops: 2012. The International Service for the Acquisition of Agri-biotech Applications (ISAAA), Ithaca, NY.

Lin, H. Y., Chiueh, L. C. and Shih, D. Y. C. (2000). Detection of genetically modified soybeans and maize by the polymerase chain reaction method. Journal of Food and Drug Analysis, 8: 200-207.

Lipp, M., Brodmann, P., Pietsch, K., Pauwels, J. and Anklam, E. (1999). IUPAC collaborative trial study of a method to detect genetically modified soybeans and maize in dried powder. Journal of AOAC International, 82: 923-928.

Marmiroli, N., Maestri, E., Gulli, M., Malcevschi, A., Peano, C., Bordoni, R. and De Bellis, G. (2008). Methods for detection of GMOs in food and feed. Analytical and Bioanalytical Chemistry, 392: $369-384$.

Murray, H.G. and Thompson, W.F. (1980). Rapid isolation of high molecular weight DNA. Nucleic Acids Research, 8: 4321-4325.

Ovesna, J., Kucera, L., Hodek, J. and Demnerova, K. (2010). Reliability of PCR based Screening for Identification and Quantification of GMOs. Czech Journal of Food Sciences, 28: 133-138.

Paoletti, C., Heissenberger, A., Mazzara, M., Larcher, S., Grazioli, E., Corbisier, P., Hess, N., Berben, G., Lubeck, P.S., De Loose, M., Moran, G., Henry, Ch., Brera, C., Folch, I., Ovesna, J. and Van den Eede, G. (2006). Kernel lot distribution assessment (KeLDA): a study on the distribution of GMO in large soybean shipments. European Food Research and Technology, 224: 129-139.

Querci, M., Jeremini, M. and Van den Eede, G. (2006). The analysis of food samples for the presence of genetically modified organisms. User Manual. JRC.

Rabiei, M., Mehdizadeh, M., Rastegar, H., Vahidi, H. and Alebouyeh, M. (2013). Detection of Genetically Modified Maize in Processed Foods Sold Commercially in Iran by Qualitative PCR. Iranian Journal of Pharmaceutical Research, 12: 25-30

Spoth, B. and Strauss, E. (1998). Screening for genetically modified organisms in food using, Promega's Wizard resin. Promega Notes, 73: 23-25.

Untergasser, A., Nijveen, H., Rao, X., Bisseling, T., Geurts, R. and Leunissen, J.A.M. (2007). Primer3Plus, an enhanced web interface to Primer3. Nucleic Acids Research, 35: 71-74.

Vrablik, A., Hodek, J., Soukup, J. and Demnerova, K. J. (2012). Development and Verification of PCR based Assay to Detect, and Quantify Garden Pea lec Gene, Czech Journal of Food Sciences, 30: $247-257$.

Wang, W. and Fang, T. (2005). Development of Multiplex and Quantitative PCR Assay to Detect Genetically Modified Roundup Ready Soybean in Foods. Journal of Food and Drug Analysis, 13: 132-138. 


\title{
Quantitative Detection of Transgenic Roundup Ready Soybean Seeds Using Real-time PCR Method
}

\author{
Elham Ghazizadeh', Amir Mousavi ${ }^{2, *}$ and Faranak Hadi ${ }^{3}$
}

1- Former M.Sc. Student, Department of Plant Biotechnology, National Institute of Genetic Engineering and Biotechnology (NIGEB), Tehran, Iran

2- Associate Professor, Department of Plant Biotechnology, National Institute of Genetic Engineering and Biotechnology (NIGEB), Tehran, Iran

3- Assistant Professor, Department of Biology, Faculty of Science, Lorestan University, Khoramabad, Iran

(Received: January 12, 2014 - Accepted: April 28, 2014)

\begin{abstract}
As genetically modified organisms (GMOs) development is now increasing, detection and determination of their quantitative threshold using reliable methods would be necessary. The goal of this study was to introduce a sensitive method for qualitative and quantitative detection of Roundupready soybean samples. For primary screening, semi-quantitative molecular assays have been used for detection of various percentages of transgenic and non-transgenic Roundup-ready soybean samples. Furthermore, an experiment was conducted using the CaMV $35 \mathrm{~S}$ primers in combinations with soybean lectin-specific primers in two imported samples of soybean seeds. Real-time PCR-based analysis indicated that the amount of GMO material in the seeds and the limit of detection (LOD) obtained for $35 \mathrm{~S}$ sequence was less than $1 \%$. The sensitivity and accuracy of this method had conformity with the international standards of seed labeling. This is the first report of its type for quantitative detection of a genetically modified material in a commercial seed lot in Iran.
\end{abstract}

Keywords: Limit of detection, Genetically modified crop, Roundup ready soybean

\footnotetext{
*Corresponding Author, E-mail: m-amir@nigeb.ac.ir
} 